\title{
PENERAPAN DIR FLOORTIME PADA ANAK DENGAN AUTISM SPECTRUM DISORDER UNTUK MENINGKATKAN KEMAMPUAN SOSIAL
}

\author{
Elita Kirana $^{1)}$, Ediasri T. Atmodiwirjo ${ }^{2)}$, dan Debora Basaria ${ }^{3)}$ \\ Program Studi Magister Psikologi, Universitas Tarumanagara, \\ ${ }^{1)}$ delicya.elita@gmail.com, ${ }^{2)}$ ediasri@gmail.com, ${ }^{3)}$ deborab@fpsi.untar.ac.id
}

\begin{abstract}
Children with autism have deficit characteristics in social communication and social interaction, as well as restricted and repetitive patterns of behavior, and limited interests or activities. As children grow and engage in a wider environment, this is become a problem because of the lack of social skills on children with autism. The purpose of this research is to improve the social skills of children with autism. There are several methods that can be applied to children with autism to improve their social skills. One of them is the DIR (Developmental, Individual Differences, \& Relationship Based) Floortime method. DIR Floortime aims to help children reach the stage of their emotional development through play activities. This type of research is a clinical case study, involving two middle childhood boys that are diagnosed with a mild level of autism. The instruments used in this study are Autism Social Skills Profile and Functional Emotional Assessment Scale. This research involves 20 sessions, conducted in May until June 2018, consisting of 10 sensory sessions and 10 symbolic sessions for each subject. The results of this research show an improvement in social skills in both participants, marked by an increase in the post test scores, but not significantly. Qualitatively, both subject demonstrates an improvement on social skills in their daily behavior after they had participated in the intervention.
\end{abstract}

Keywords: autism spectrum disorder, middle childhood, DIR Floortime, social skills

ABSTRAK: Anak autistik memiliki karakteristik kesulitan dalam komunikasi dan interaksi sosial serta adanya yang minat terbatas, perilaku berulang, atau keterikatan dalam minat dan aktivitas. Hal ini menjadi masalah saat anak tumbuh seiring usia dan terlibat dalam lingkungan yang lebih luas karena kurangnya kemampuan sosial pada anak autistik. Penelitian ini bertujuan untuk meningkatkan kemampuan sosial anak autistik. Ada beberapa metode yang dapat diterapkan pada anak autistik untuk meningkatkan kemampuan sosial. Salah satunya adalah metode DIR (Developmental, Individual Differences, \& Relationship Based) Floortime. DIR Floortime bertujuan membantu anak mencapai tahap perkembangan emosionalnya melalui kegiatan bermain. Jenis penelitian ini adalah case study yang melibatkan dua orang partisipan, yaitu anak laki-laki berusia middle childhood dengan autisme level Mild. Instrumen dalam penelitian ini adalah Autism Social Skills Profile dan Functional Emotional Assesment Scale. Penelitian ini berlangsung selama 20 sesi intervensi yang dilaksanakan pada bulan Mei hingga Juni 2018. Sesi intervensi terdiri dari 10 sesi sensori auditori dan 10 sesi simbolik bagi masing-masing subjek. Hasil penelitian menunjukkan adanya peningkatan yang signifikan pada kapasitas emosi, tetapi kemampuan sosial kedua partisipan tidak meningkat secara signifikan. Secara kualitatif, kedua subjek menunjukkan kemampuan sosial yang lebih baik setelah mengikuti sesi intervensi, hal ini tampak dalam perilaku sehari-hari.

Kata kunci: autisme, middle childhood, DIR Floortime, kemampuan sosial

\section{PENDAHULUAN}

Leo Kanner pada tahun 1943 pertama kali mendeskripsikan kata autisme untuk merujuk pada anak yang mengalami gangguan perkembangan bahasa dan sosialisasi (Dixon, Tarbox, \& Najdowski, 2010). Kemunculannya secara resmi pada tahun 1980 di DSM III menjadikan penelitian mengenai autisme semakin meningkat dari waktu ke waktu (Volkmar
\& Pelphrey, dalam Blaney, Krueger, Millon, 2015). Autisme kemudian dipahami sebagai disabilitas perkembangan yang berlangsung seumur hidup akibat dari fungsi otak yang abnormal (Sharpe \& Baker, 2007). Austism spectrum disorder mencakup rangkaian perbedaan dan kemampuan yang sangat luas (Levesque, 2011). Pada umumnya, anak autistik menunjukkan tantangan dalam 2 macam area. Area pertama adalah fondasi dasar 
dalam hubungan, komunikasi, dan berpikir, seperti kesulitan dalam komunikasi sosial timbal balik, yang merupakan dasar dari hubungan. Area kedua adalah gejala-gejala khusus seperti perilaku repetitif, stimulasi diri, dan self absorption (APA, 2013). Di Indonesia sendiri, Judarwanto memperkirakan bahwa pada tahun 2015 terdapat 1 dari 250 anak mengalami autisme, sehingga kurang lebih terdapat 12.800 anak dengan autisme dan 134.000 orang dengan autisme (Apa Kabar Anak dengan Autisme di Indonesia, 2017).

Walaupun berangkat dari kesamaan kriteria autisme, tetapi anak autistik menunjukkan gejala utama yang berbeda satu sama lain. Menurut Mash dan Wolfe (2013), hal ini dipengaruhi oleh tiga hal, yaitu: (1) tingkat kecerdasan individu, yaitu anak dapat berada dari rentang profound hingga kecerdasan diatas rata-rata. (2) tingkat keparahan gangguan bahasa, yaitu anak dengan ASD dapat berada pada titik di manapun antara 2 ekstrim, yaitu diam dan banyak bicara, serta (3) perubahan perilaku seiring usia, yaitu beberapa anak menunjukkan sedikit kemajuan, sementara beberapa anak mengembangkan bicara atau lebih bersosialiasi, yang biasanya dipengaruhi oleh tingkat kecerdasan anak dan mendapat terapi wicara sejak dini.

Pada saat anak memasuki usia sekolah, hubungan antara orang tua dan anak mengalami perubahan. Sementara itu, menjalin hubungan dengan teman sebaya memberi dampak penting dalam konteks perkembangan anak, seperti berkontribusi dalam pemahaman diri dan orang lain. Pertemanan juga mengembangkan rasa percaya dan sensitivitas (Berk, 2014). Selain itu, interaksi positif dengan teman juga membantu perkembangan kemampuan sosial seperti kemampuan interpersonal, kemampuan komunikasi, pemahaman dan regulasi emosi, serta kemampuan mengontrol perilaku agresif ("Social Skills", 2009). Namun, sulit untuk memastikan bahwa semua anak dapat berada di sekolah dan mengetahui bagaimana harus berperilaku dan memberi respons yang sesuai pada berbagai situasi sosial (Johns, Crowley, \& Guetzloe, 2005).
Anak dengan masalah perilaku akan menunjukkan defisit pada kemampuan sosial, karena memberikan respons pada stimulus sosial yang ada dengan cara yang tidak terprediksi (Shores \& Jack, 1996).

Anak autistik cenderung mengalami kesulitan dalam kemampuan sosial yang berhubungan dengan interaksi orang lain baik langsung maupun tidak langsung. Umumnya, kekurangan kemampuan sosial anak dengan ASD melibatkan area berbicara, kaidah bahasa, dan interaksi interpersonal (White \& Keonig, 2007). Tanda adanya gangguan sosial pada anak autistik juga tampak pada rendahnya komunikasi verbal dan nonverbal, rendahnya kemampuan meniru, kurangnya afeksi normal, buruknya atau tidak adanya kelekatan, kurangnya minat terhadap orang lain, dan rendahnya aktivitas imajinatif seperti bermain (Pelios \& Lund, 2001). Defisit kemampuan sosial ini berpengaruh pada interaksi anak dengan keluarga, teman sebaya, dan orang dewasa lain (Rao, Beidel, \& Murray, 2008). Defisit kemampuan sosial yang terus menerus menjadikan anak dengan autisme kesulitan membentuk sebuah hubungan (Tse, Strulovitch, Tagalakis, Meng \& Fombonne, 2007).

Sementara itu, beberapa penelitian mengenai metode intervensi autisme telah banyak terbukti secara ilmiah berdampak signifikan, misalnya: (a) Applied Behavior Analyis (ABA), (b) Discrete Trial Training (DTT), serta (c) Functional Communication Training (FCT). Sementara itu, beberapa jenis intervensi yang menjanjikan bagi penanganan autisme adalah: (a) play therapy, (b) supportive therapies, dan (c) developmental relationship-based treatment atau DIR Floortime (Lindgren \& Doobay, 2011). The Developmental, Individual Difference, Relationship-Based, atau dikenal dengan DIR Floortime adalah model kerangka interdisipliner yang memungkinkan orang tua, pendidik, atau tenaga klinis bermain sekaligus melakukan asesmen menyeluruh dan melaksanakan program intervensi yang komprehensif, dengan mengembangkan keunikan anak dan keluarga yang sesuai dengan profil defisit pada anak (Hess, 2013). 
The Autism Society of America memperkirakan biaya merawat anak dengan ASD sepanjang usia berkisar antara 3,5 juta sampai dengan 5 juta US Dolar, yang termasuk dalam penelitian, kesehatan, pendidikan, tempat tinggal, terapi, dan biaya pengasuh (Lindgren \& Doobay, 2011). Sementara itu, DIR Floortime dikenal sebagai metode intervensi yang berbiaya rendah dan dapat diaplikasikan oleh profesional sebagai konsultan sementara orang tua berperan sebagai model terapis (Pajareya \& Nopmaneejumruslers, 2011). DIR Floortime dikembangkan oleh Stanley Greenspan pada awal 1990an untuk mendorong orang dewasa terlibat dalam sesi bermain terstruktur dan spontan yang bertujuan membangun hubungan, keterikatan sosial, berpikir kompleks, dan pemecahan masalah pada anak dengan ASD (Lang, Hancock, \& Singh, 2016). Secara sederhana, Floortime dipahami sebagai teknik di mana orang dewasa turun ke lantai dan bermain serta bekerja sama dengan anak selama 20 menit atau lebih untuk menguasai kapasitas perkembangan dengan memahami perbedaan kondisi emosi, sosial, dan intelektual anak, serta perbedaan motorik, sensori, dan fungsi bahasa anak (Hess, 2013).

Komponen utama dari DIR Floortime adalah interaksi sosial timbal balik, yang dinamakan lingkaran komunikasi (Lang, Hancock, \& Singh, 2016). Aspek penting dari DIR Floortime adalah pemahaman pada aspek penting kapasitas anak yang butuh dikembangkan, dibandingkan faktor perilaku (Mercer, 2015). Tujuan penerapan Floortime antara lain mendorong munculnya atensi dan keakraban, komunikasi dua arah, mendorong munculnya ekspresi dan penggunaan perasaan serta gagasan, dan pemikian logis (Greenspan \& Wieder, 2008).

Anak dengan autisme kesulitan mencapai tahapan dalam bermain karena adanya masalah motorik kasar atau halus, komunikasi ekspresif atau reseptif, dan imitasi, yang menjadi halangan bagi anak autisme dalam bermain (Hess, 2013).
Metode DIR Floortime termasuk dalam format pendekatan perilaku naturalistik, yang berbeda dengan pendekatan lain karena mengajarkan anak pada situasi tidak terstruktur seperti bermain, kesempatan belajar diawali oleh anak, dan penggunaan bantuan, penguatan, maupun fading (Dixon, Tarbox, \& Najdowski, 2010). Keuntungan dari penerapan metode ini dalam mengajarkan kemampuan sosial adalah banyak kemampuan sosial terjadi pada kondisi tidak terstuktur karena memang seharusnya terjadi, seperti kemampuan berbincang pada jam makan siang, kemampuan berbagi pada saat bermain, kemampuan giliran pada saat bermain permainan tertentu, dan lainnya (Dixon, Tarbox, \& Najdowski, 2010).

DIR Floortime di Indonesia dikembangkan oleh Yayasan Ayo Main! dan masih jauh dari jangkauan masyarakat Indonesia karena keterbatasan informasi dan sumberdaya manusia yang mendalami pendekatan ini. Padahal, pendekatan ini amat ideal diterapkan pada daerah dengan tingkat kemiskinan yang tinggi karena dapat dipelajari, dimulai dan diterapkan secara mandiri di rumah maupun disekolah (Komunitas DIR/Floortime Indonesia, 2009). Penelitian penerapan Floortime di Indonesia sendiri juga masih terbatas, namun menunjukkan hasil yang positif. Misalnya saja, 'Pengaruh Penerapan Floortime terhadap Kemampuan Berbahasa Pada Anak Autistik' oleh Pangestika (2013) pada 3 orang subyek yang mengalami peningkatan kemampuan bahasa setelah mengikuti sesi Floortime. Hal ini menjadikan peneliti ingin mengetahui dampak dari penerapan DIR Floortime pada anak usia middle childhood dengan Autism Spectrum Disorder untuk meningkatkan kemampuan sosial.

\section{Autism Spectrum Disorder}

Autisme berasal dari kata "Autos" yang berarti diri sendiri dan "isme" yang berarti suatu paham atau aliran sehingga, autism diartikan sebagai suatu paham atau aliran yang tertarik pada dunianya sendiri (Suryana, 2004). Wall (2004) menyatakan autisme sebagai anak yang tidak tertarik 
pada dunia sekitarnya. Secara harafiah autism dapat diartikan sebagai ketertarikan pada dunianya sendiri dan tidak pada dunia di luar dirinya. Autism Spectrum Disorder adalah kelompok dari disabilitas perkembangan neuro yang didefinisikan dengan penurunan signifikan pada interaksi sosial, defisit pada komunikasi, dan adanya perilaku kaku atau minat yang terbatas (Lindgren \& Doobay, 2011).

\section{Kemampuan Sosial}

Kemampuan sosial adalah perilaku belajar yang melibatkan interaksi dengan orang lain di mana memungkinkan individu untuk mampu berfungsi secara kompeten dalam tugas sosial (Cook, Gresham, Barreras, Thornton, and Crews, 2008). Kemampuan sosial melibatkan perilaku belajar spesifik dari inisiatif dan respons perilaku, serta membutuhkan interaksi dengan orang lain (Little, Swangler, AkinLittle, 2017).

Bellini dan Hopf (2007) merumuskan aspek dalam kemampuan sosial adalah timbal balik sosial, partisipasi sosial atau menarik diri, dan perilaku sosial mengganggu. Timbal balik sosial, merujuk pada kemampuan yang diperlukan untuk menjaga keberhasilan interaksi timbal balik sosial. Partisipasi sosial atau menarik diri, yaitu merujuk pada keterlibatan sosial atau penarikan diri dari partisipasi sosial. Perilaku sosial menganggu, merujuk pada perilaku tidak pantas yang dapat mengarah pada interaksi negatif dengan teman sebaya.

\section{DIR Floortime}

DIR Floortime adalah pendekatan pragmatis sosial yang digunakan untuk membantu anak dengan autisme mengembangkan kemampuan verbal dan sosial, dan dikembangkan oleh Dr. Stanley Greenspan melalui permainan dalam rangka membangun lingkungan natural yang membantu anak mencapai tahap perkembangan bahasa dan kemampuan sosial yang sesuai (Matheson, 2016). DIR adalah singkatan dari The Developmental, Individual Difference, Relationship-based, yaitu sebuah kerangka yang membantu petugas klinis, orang tua dan pendidik untuk melakukan asesmen menyeluruh dan mengembangkan program intervensi yang menyasar pada tantangan keunikan dan kekuatan anak dengan ASD atau gangguan perkembangan lainnya. Tujuan dari DIR Floortime a dalah membangun fondasi yang sehat bagi kapasitas intelektual, emosi, dan social dibandingkan mengembangkan kemampuan atau mengisolasi perilaku tertentu (Greenspan \&Wieder, 2008). Secara umum, terdapat 6 tahapan perkembangan fungsi emosi dalam konsep DIR Floortime mengacu pada ICDL-DMIC (2005).

\section{METODE PENELITIAN}

Partisipan dalam penelitian ini adalah dua orang anak laki-laki yang memiliki karakteristik sebagai berikut: (1) berusia middle childhood, (2) telah didiagnosa dengan autism spectrum disorder, level mild, (3) taraf kognitif berada dalam rentang disabilitas intelektual, khususnya kategori moderate, dan (4) mendapat terapi lain seperti terapi wicara, okupasi, dan fisioterapi. Selain itu, kedua subjek merupakan siwa di sebuah SD-SLB di daerah Jakarta Barat, yaitu SLB Tr.

Penelitian ini menggunakan Clinical Case Study dengan A-B design. Autism Social Skills Profile dianalisis untuk mengetahui perbandingan hasil sebelum dan sesudah pemberian intervensi.

Dalam pengukuran, Autism Social Skills Profile (ASSP) digunakan untuk mengukur variable dependen dalam penelitian ini, yaitu kemampuan sosial. ASSP terdiri dari 45 item yang mengukur fungsi sosial anak dan remaja dengan ASD mengacu pada tiga bagian skala, yaitu timbal balik sosial, partisipasi sosial atau menarik diri, dan perilaku sosial mengganggu. Terdapat 23 item pada dimensi timbal balik sosial, 12 item pada dimensi partisipasi sosial atau menarik diri, dan 10 item pada bagian perilaku mengganggu. 33 butir merupakan bentuk pernyataan positif, sedangkan 12 butir dalam bentuk pernyataan negatif. Contoh butir pertanyaan dalam ASSP adalah 
"Mengajak teman sebaya untuk bergabung dalam kegiatannya".

Selain itu, Functional Emotional Assesment Scale (FEAS) dari Greenspan dan DeGangi (2000) digunakan sebagai instrumen observasi pada setiap sesi DIR Floortime. FEAS terdiri 33 butir pernyataan perilaku yang terdiri dari 6 subtes, yaitu berasal dari 6 tonggak perkembangan dari Greenspan: (1) regulasi diri, (2) keakraban, (3) komunikasi 2 arah, (4) komunikasi kompleks, (5) gagasan emosional, dan (6) berpikir emosional. Sistem skoring FEAS menggunakan skala 0 sampai 2 untuk setiap tonggaknya. Skor kemudian dapat dijumlahkan per subtes maupun secara keseluruhan untuk mendapat total skor. Semakin tinggi skor FEAS mengindikasikan semakin tingginya kapasitas fungsi emosi anak. Norma FEAS mengacu pada Greenpan, DeGangi dan Wider pada tahun 2001, yaitu $0-45$ poin kategori kurang, 46-47 poin kategori resiko, dan 48-66 kategori normal.

Pada dua orang anak laki-laki dari SLB Tr yang memenuhi kriteria partisipan yaitu berusia middle childhood, telah didiagnosa dengan autism level Mild, dan mendapat terapi lain, peneliti melakukan observasi dan wawancara pada orang tua maupun guru untuk mengetahui aspek Developmental, Individual Differences, dan Relationship. Subjek kemudian mengikuti 5 sesi baseline dengan menggunakan alat ukur Functional Emotional Assesment Scale untuk mengetahui tingkat perkembangan emosi dan pre-test Autism Social Skills Profile untuk mengetahui kemampuan sosial keduanya. Dua macam sesi kemudian dirumuskan, yaitu sesi sensori auditori dan sesi simbolik berdasarkan preferensi subjek. Terdapat 20 sesi dilaksanakan, dengan setiap sesinya berlangsung 20-30 menit dan 2-3 sesi setiap harinya. Alat ukur ASSP kembali diadministrasikan setelah sesi terakhir intervensi dan dilaksanakan juga 5 sesi post-test. Hasil pre-tes dan post-tes untuk alat ukur FEAS dan ASSP kemudian akan di uji dengan Wilcoxon untuk mengetahui dampak dari program intervensi terhadap perkembangan emosi dan kemampuan sosial. Selain itu, peneliti memberikan pelatihan kepada orang tua dan menghimbau agar menerapkannya di rumah. Kemudian, peneliti melakukan monitoring dan evaluasi kepada subjek selama 2 minggu.

Intervensi ini terdiri dari 5 sesi pretest, 20 sesi intervensi, dan 5 sesi post-test. Setiap sesi dilaksanakan pada jam sekolah, dimana setiap harinya terdiri dari 2-3 sesi, masing-masing sesi berdurasi 20-30 menit. Sehingga, total waktu yang dibutuhkan untuk pelaksanaan intervensi adalah 2 hari untuk sesi pre-test, 7 hari untuk sesi intervensi, dan 2 hari untuk sesi post-test.

Setiap anak mendapatkan 2 macam sesi, yaitu sesi permainan sensori dan sesi permainan simbolik berdasarkan profil keunikan individu. Hal ini ditentukan berdasar hasil observasi terhapap subjek dan wawancara terhadap orang tua maupun guru sebelum intervensi. Kebetulan, kedua subjek sama-sama memiliki preferensi sensori berupa auditori, sehingga rancangan permainan sensori subjek $\mathrm{M}$ dan $\mathrm{H}$ sama. Sementara itu, rancangan permainan simbolik bagi subjek $\mathrm{H}$ berdasarkan pada minatnya pada makanan dan kereta, sedangkan rancangan permainan subjek $M$ berdasarkan pada minatnya yang lebih besar pada mobil dan alat transportasi.

\section{HASIL DAN PEMBAHASAN}

Pada sesi intervensi 1 hingga sesi 20, dilakukan observasi secara mendetail untuk mendapat gambaran dari subjek secara menyeluruh. Khususnya, dalam area perkembangan kapasitas emosi subjek. Berikut adalah grafik yang menggambarkan uraian total skor FEAS subjek H sejak sesi 1 hingga sesi 20 intervensi DIR Floortime.

Gambar 1. Skor FEAS sesi intervensi H

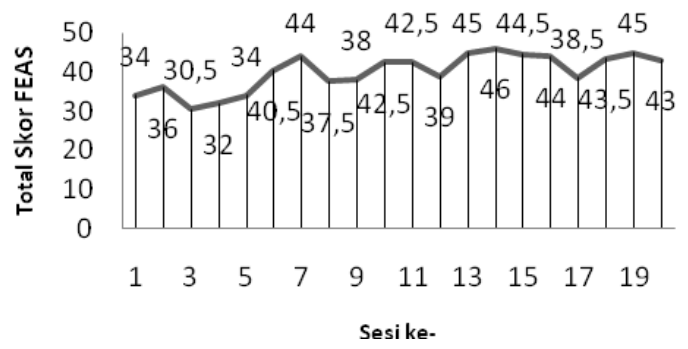


Pada $\mathrm{H}$, secara umum grafik $\mathrm{H}$ menunjukkan peningkatan ke arah yang lebih tinggi. Namun, pada beberapa sesi terjadi penurunan skor dibanding sesi-sesi sebelumnya. $\mathrm{H}$ menunjukkan skor terendah pada 3 sesi di pertemuan 1. Hal ini tampaknya dikarenakan intervensi baru berjalan, sehingga $\mathrm{H}$ yang sejak awal sesi baseline cenderung pasif dan bermain dalam dunianya sendiri serta tidak menanggapi peneliti. $\mathrm{H}$ seperti belum terbiasa dan juga belum berminat mengeksplorasi mainan. Sesi-sesi selanjutnya menunjukkan skor $\mathrm{H}$ cenderung dalam arah meningkat.

Di sisi lain, pada sesi 7, 14, dan 19, $\mathrm{H}$ menunjukkan skor yang tinggi. Hal ini tampaknya dipengaruhi oleh kesadaran $\mathrm{H}$ sejak awal bahwa ia akan mengikuti sesi dengan peneliti. $\mathrm{H}$ menarik tangan peneliti dan menuju ruang guru untuk meminta ijin akan mengikuti sesi dengan peneliti, tanpa peneliti mengajaknya terlebih dahulu. $\mathrm{H}$ pun kemudian bersemangat menuju ruangan intervensi dan antusias mengambil sendiri mainan singing bird kesukaannya. Selain itu, pada sesi-sesi tersebut $\mathrm{H}$ juga menunjukkan variasi minat untuk bermain berbagai macam mainan yang ada di hadapannya, sehingga $\mathrm{H}$ mendapat kesempatan mengeksplorasi berbagai mainan dan membuatnya dapat mengeluarkan berbagai gagasan emosional dalam permainannya.

Berikut adalah grafik yang menggambarkan uraian total skor FEAS subjek M sejak sesi 1 hingga sesi 20 intervensi DIR Floortime.

Gambar 2. Skor FEAS sesi sntervensi M

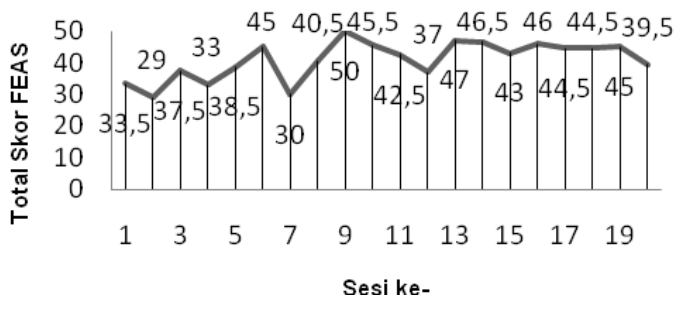

Berdasarkan grafik 2, M menunjukkan skor yang rendah pada sesi 2 dan sesi 7. Hal ini tampaknya dipengaruhi oleh kondisi $M$ sebelum mengikuti intervensi, yaitu kurang tidur sejak dari rumah. Sejak pagi hari datang ke sekolah, $M$ berceloteh dan marah-marah terus menerus, hingga ayah dan ibunya harus menenangkannya. Saat pelajaran di kelas pun, $\mathrm{M}$ berulang mengucapkan bahwa ia ingin tidur dan marah saat di tegur. Bahkan, M sempat dibiarkan oleh sang guru agar terlelap untuk beberapa saat karena kondisi $M$ yang sudah tidak kondusif untuk mengikuti pelajaran dan juga menganggu teman-temannya. Saat dikonfirmasi kepada sang ibu, ternyata pada malam hari $\mathrm{M}$ bangun dan mencari handphone sang ibu yang disembunyikan, kemudian memainkannya sepanjang malam tanpa sepengetahuan sang ibu.

Sementara itu, pada sesi 9, M menunjukkan skor yang sangat tinggi hingga 50 poin karena suasana hati $\mathrm{M}$ yang baik sejak pagi dan $M$ yang sangat menantinantikan saatnya untuk mengikuti sesi intervensi bersama peneliti. Sejak pagi, M antusias mengatakan kepada gurunya bahwa ia mau bermain dengan peneliti dan berkali-kali mengintip ke ruangan tempat intervensi biasa berlangsung. Hal ini menjadikan $M$ sangat ceria sepanjang bermain dan juga mampu menunjukkan perasaannya kepada peneliti maupun berempati kepada peneliti. M juga dapat bermain dengan lebih variatif dan mengembangkan ide-ide berisi gagasan emosional.

Evaluasi Perkembangan Kapasitas Emosi

Hasil perbandingan perolehan skor pre-test dan post-test pada alat ukur FEAS dapat dilihat pada tabel 1 .

Tabel 1. Perbandingan skor FEAS baseline dan post-test

\begin{tabular}{llllc}
\hline & \multicolumn{2}{c}{$\mathrm{H}$} & \multicolumn{2}{c}{$\mathrm{M}$} \\
$\begin{array}{l}\text { Sesi } \\
\text { ke- }\end{array}$ & $\begin{array}{l}\text { Base- } \\
\text { line }\end{array}$ & $\begin{array}{l}\text { Post } \\
\text { test }\end{array}$ & $\begin{array}{l}\text { Base- } \\
\text { line }\end{array}$ & $\begin{array}{l}\text { Post } \\
\text { test }\end{array}$ \\
\hline 1 & 21,5 & 33,5 & 32 & 47,5 \\
2 & 32,5 & 40,5 & 37 & 43 \\
3 & 29,5 & 38,5 & 37 & 41,5 \\
4 & 31,5 & 38,5 & 39,5 & 45,5 \\
5 & 33,5 & 28,5 & 40 & 43 \\
$\begin{array}{l}\text { Rata- } \\
\text { rata }\end{array}$ & 29,7 & 35,9 & 37,1 & 44,1 \\
\hline
\end{tabular}


Berdasarkan tabel diatas, dapat diketahui bahwa subjek $M$ dan subjek $H$ secara umum sama-sama mengalami peningkatan pada area kapasitas emosi subjek setelah mengikuti sesi intervensi DIR Floortime. Namun, rata-rata skor pretest dan post-test subjek $\mathrm{H}$ dan $\mathrm{M}$ masih berada pada kisaran 0-45, yaitu tergolong dalam kategori kurang menurut Greenspan, DeGangi dan Wider (2001). Sementara, berikut merupakan hasil uji statistik pre-test dan post-test skor FEAS.

Tabel 2. Uji signifikasi skor FEAS baseline dan post-test

\begin{tabular}{cl}
\hline & Baseline - post-test \\
\hline $\mathrm{Z}$ & $-2,499^{\mathrm{b}}$ \\
$\begin{array}{c}\text { Asymp. Sig. } \\
\text { (2-tailed) }\end{array}$ &, 012 \\
\hline
\end{tabular}

Berdasarkan tabel 2 dapat disimpulkan bahwa DIR Floortime efektif meningkatkan kapasitas emosi pada subjek secara signifikan $(p<0,05)$. Hal ini dilihat dari perbedaan skor tonggak perkembangan keseluruhan yang di observasi dari 5 sesi baseline dan 5 sesi post-test.

\section{Evaluasi Kemampuan Sosial}

Berikut merupakan hasil ringkasan perbandingan perolehan skor pre-test dan post-test pada alat ukur ASSP kedua subjek.

Tabel 3. Perbandingan pre-test dan posttest ASSP

\begin{tabular}{lcccc}
\hline & \multicolumn{2}{c}{ Subjek H } & \multicolumn{2}{c}{ Subjek M } \\
& Pre & Post & Pre & Post \\
\hline $\begin{array}{l}\text { Timbal balik } \\
\text { sosial }\end{array}$ & 2,15 & 2,19 & 1,76 & 1,95 \\
$\begin{array}{l}\text { Partisipasi } \\
\text { sosial }\end{array}$ & 2,13 & 2,2 & 2,2 & 2,33 \\
$\begin{array}{l}\text { Perilaku } \\
\text { sosial }\end{array}$ & 2,7 & 3 & 2,5 & 2,45 \\
$\begin{array}{l}\text { mengganggu } \\
\text { Rata-rata }\end{array}$ & 2,32 & 2,47 & 2,16 & 2,25 \\
\hline
\end{tabular}

Berdasarkan skor pada alat tes Autism Social Skills Profile, subjek M dan subjek H sama-sama mengalami peningkatan pada tiga dimensi kemampuan sosial. Secara menyeluruh, $\mathrm{H}$ mengalami peningkatan sebesar 0,14 poin, sedangkan M sebesar 0,09 poin. Pada subjek $\mathrm{H}$, tampak bahwa $\mathrm{H}$ mengalami peningkatan pada seluruh aspek, yaitu timbal balik sosial, partisipasi sosial, dan perilaku sosial menganggu. Peningkatan terbesar pada $\mathrm{H}$ terlihat pada dimensi perilaku sosial mengganggu, yaitu hingga 0,3. Hal ini menunjukkan bahwa $\mathrm{H}$ perilaku sosial mengganggu $\mathrm{H}$ cenderung menurun. Sementara itu, subjek $M$ menunjukkan peningkatan pada dimensi timbal balik sosial dan partisipasi sosial, namun mengalami penurunan pada aspek perilaku sosial menganggu. Peningkatan tertinggi terdapat pada dimensi timbal balik sosial, yaitu sebesar 0,19. Namun, M menunjukkan adanya penurunan pada dimensi perilaku sosial mengganggu sebesar 0,05. Peneliti kemudian melakukan uji statistika untuk mengetahui signifikasi dari perubahan skor pre-test ke post-test.

Tabel 4. Uji signifikasi pre-test dan posttest ASSP

\begin{tabular}{ll}
\hline & Pre-test-post-test \\
\hline$Z$ & $-1,782^{\mathrm{b}}$ \\
Asymp. Sig. & 0,075 \\
(2-tailed) & \\
\hline
\end{tabular}

Berdasarkan hasil uji signifikansi pada tabel 4.23, dapat disimpulkan bahwa peningkatan skor kedua subjek tergolong tidak signifikan $(\mathrm{p}>0,05)$. Hasil ini dikarenakan skor peningkatan dari pre-test ke post-test tidak cukup signfikan menggambarkan adanya perubahan berarti. Namun, peningkatan kemampuan sosial kedua subjek dapat diketahui secara kualitatif.

\section{DISKUSI}

Berdasarkan kesimpulan penelitian, diketahui bahwa DIR Floortime dapat meningkatkan kemampuan sosial pada anak autistik, walau tidak signifikan. Hasil ini sejalan dengan penelitian dari Lal dan Chhabria (2013) bahwa intervensi Floortime dapat meningkatkan kemampuan sosial pada anak dengan ASD. Namun, hasil yang tidak signifikan kemungkinan 
dipengaruhi oleh beberapa faktor. Adanya peningkatan signifikan pada perkembangan emosi, namun hasil yang tidak signifikan pada kemampuan sosial menunjukkan perbedaan keduanya, yaitu internal dan eksternal. Perkembangan emosi yang lebih bersifat internal tampaknya lebih mudah terlihat oleh orang di sekitarnya, sementara kemampuan sosial yang bersifat eksternal, cenderung membutuhkan waktu yang lebih panjang untuk dikenali perubahannya oleh orang di sekitar subjek.

Faktor lain adalah kapasitas kognitif pada kedua subjek penelitian yang berada pada taraf disabilitas intelektual. Individu dengan autisme dan disabilitas intelektual berimplikasi pada prognosis yang lebih buruk dan intensitas intervensi yang dibutuhkan, yaitu membutuhkan bantuan yang jauh lebih individual dibandingkan individu lain tanpa autisme pada level inteligensi yang sama (Howlin, 2000).

Berdasarkan perbandingan hasil penelitian, subjek $\mathrm{H}$ menunjukkan peningkatan skor kemampuan sosial yang lebih baik dibanding subjek M. Menurut Ryan et al (2011), DIR Floortime diketahui memberikan kesempatan bagi individu untuk mengalami tahapan penting dalam bermain yang kurang dialami oleh individu sebelumnya. Individu pun menjadi lebih menikmati proses menjalin hubungan melalui pemahaman profil sensori dan motoriknya yang diterapkan dalam sesi DIR Floortime (Greenspan, 2001). Manfaat DIR Floortime inilah yang tampaknya $\mathrm{H}$ alami sehingga $\mathrm{H}$ menunjukkan kemampuan sosial yang tadinya belum ada pada diri $\mathrm{H}$. Namun, subjek $M$ mengalami peningkatan skor fungsi emosi yang lebih tinggi dibandingkan subjek $\mathrm{H}$. Menurut Greenspan (2001), DIR Floortime juga menjadikan subjek lebih mampu dalam interaksi timbal balik, negosiasi, dan menyampaikan mengenai apa yang ia rasakan. Individu juga lebih dapat mengekspresikan kebutuhan, keinginan, pikiran dan perasaannya (Sulungbudi, 2013). Manfaat DIR Floortime ini yang mempengaruhi $\mathrm{M}$ sehingga menjadi lebih mampu untuk mengekspresikan dirinya dan berpengaruh pada peningkatan fungsi emosi pada diri $\mathrm{M}$.

Temuan menarik lainnya adalah dalam hal kapasitas fungsi emosional yang tidak lepas dari kemampuan kognitif. $\mathbf{M}$ yang memiliki tingkat inteligensi lebih unggul dari $\mathrm{H}$ menunjukkan rentang skor kapasitas fungsi emosional yang lebih tinggi dibandingkan $H$. Semakin tinggi tingkat inteligensi, maka semakin besar kapasitas individu untuk menunjukkan perbedaan, mengekspresikan afeksi, dan menggunakannya dalam interaksi untuk berkomunikasi dan memecahkan masalah (Greenspan, 2001).

M juga menunjukkan peningkatan skor pada sesi post-test dibandingkan sesi baseline dan sesi intervensi, sementara $\mathrm{H}$ mengalami penurunan pada sesi post-test dibandingkan sesi intervensi. Perbedaan hasil ini menggambarkan bahwa intervensi DIR Floortime lebih bersifat permanen pada $M$ dibanding pada diri $\mathrm{H}$. Kondisi yang mempengaruhi perbedaan hasil pada $\mathrm{H}$ adalah $\mathrm{H}$ yang tidak mampu mencapai tonggak perkembangan pertama secara mandiri selama sesi post-test tanpa adanya peneliti sebagai fasilitator yang mengikuti tuntunan anak. Menurut Hess (2013), saat individu tidak mampu mencapai tonggak regulasi diri, maka individu akan kesulitan untuk belajar dari pengalaman bermain dan bergerak ke arah tahap perkembangan selanjutnya.

Di samping itu, kedua subjek samasama menunjukkan penurunan skor pada sesi-sesi tertentu. Secara umum, kondisi ini dipengaruhi oleh munculnya periode skimming, scripting dan tantrum sehingga keduanya menunjukkan kesulitan keduanya dalam mengelola dorongan dalam diri. Kondisi ini tampaknya dipengaruhi oleh fungsi eksekutif anak dengan autisme yang cenderung kurang dalam inhibisi respons, yaitu kemampuan untuk menekan informasi atau dorongan yang tidak sesuai dan menganggu (Robinson et al, 2009).

Sementara itu, kedua subjek juga mengalami penurunan skor setelah hari libur dan tidak mengikuti sesi intervensi. Kedua subjek sama-sama banyak menghabiskan waktu dengan handphone 
dan menonton Youtube. Media diketahui memberi dampak pada perkembangan anak, khususnya dalam area psikososial, seperti munculnya perilaku anti soial dan kesulitan regulasi diri (Canadian Paediatric Society, 2017). Waktu penggunaan gadget secara tidak langsung juga berdampak pada kurangnya waktu tidur keduanya. Jam tidur di malam hari tidak secara kuat memprediksi masalah perilaku di hari berikutnya, namun durasi tidur selama 8 hari memprediksi masalah perilaku pada anak dengan autisme (Cohen et al, 2019).

Sementara itu, tingginya tingkat paparan media pada anak berhubungan dengan rendahnya level stimulasi di rumah dan kurangnya keterlibatan orang tua pada anak (Canadian Paediatric Society, 2017). Kondisi inilah yang terjadi pada kedua subjek di mana status orang tua yang merupakan ibu rumah tangga dengan anak lebih dari 1 dan ayah bekerja, sehingga ibu merupakan figur tunggal dalam mengurus kebutuhan rumah tangga.

Terdapat juga keterbatasan pada penelitian ini. Keterbatasan penelitian yang pertama adalah keterbatasan waktu penelitian, sehingga peneliti hanya melaksanakan 20 sesi intervensi yang dilaksanakan dalam 7 hari saja karena benturan dengan jadwal kegiatan anak di sekolah. Selain itu, subjek juga mengalami banyak hari libur, baik hari libur nasional maupun hari libur dari sekolah. Hal ini berpengaruh pada pelaksanaan sesi yang tidak beruntun, namun terpotong jeda hari libur. Keterbatasan kedua adalah peneliti yang memilih menggunakan pedoman tonggak perkembangan sebagai kesatuan yang dinamis. Hal ini menjadikan peneliti tidak fokus untuk mencapai salah satu tonggak saja dalam melaksanakan intervensi. Sehingga, terkadang setiap sesinya berjalan terlalu luas dan tidak terarah, serta tidak dapat menggambarkan seluruh indikator perilaku dari skala lengkap FEAS dalam pengukuran perilakunya karena penelitian ini berangkat dari asumsi bahwa perkembangan emosi anak dapat meningkatkan kemampuan sosial. Keterbatasan ketiga adalah sulitnya replikasi penelitian serupa karena penelitian ini dibuat berdasarkan keunikan subjek pada area fisik, kognitif, dan psikososial. Sehingga, adalah hal yang sangat mustahil untuk menemukan subjek dengan kriteria yang sama persis dengan penelitian ini. Keterbatasan lain adalah tidak adanya kelompok kontrol dan kontrol dari peneliti terhadap kondisi subjek menjadikan sulitnya mengetahui dampak faktor eksternal yang tidak terduga terhadap hasil intervensi.

\section{SIMPULAN DAN SARAN}

Berdasarkan hasil analisa yang dilakukan terhadap data hasil penelitian, kedua subjek menunjukkan adanya peningkatan signifikan dalam tonggak perkembangan. Peningkatan ini tampak dari mulai bergeraknya jenis permainan individu ke tonggak ke-5, yaitu gagasan emosional. Selain itu, kedua subjek juga menunjukkan adanya peningkatan kapasitas emosi.

Sementara itu, penerapan DIR Floortime untuk meningkatkan kemampuan sosial pada anak dengan autisme belum menunjukkan hasil yang signifikan, walaupun terdapat perubahan secara kualitatif pada subjek.

Saran

Saran yang dapat diberikan oleh peneliti bagi penelitian selanjutnya, antara lain: (a) pelaksanaan sesi dengan jumlah sesi yang lebih banyak dan waktu yang lebih panjang, (b) sesi intervensi menyasar pada 1 tonggak yang hendak dikembangkan, dan (c) melaksanaan penelitian dengan jumlah partisipan yang lebih banyak.

Saran kepada orang tua untuk meningkatkan kemampuan sosial anak autistik adalah mempelajari metode DIR Floortime serta orang tua dapat menerapkanya di rumah secara rutin, terutama jenis permainan yang sesuai dengan profil anak dan kemungkinan anak lebih mampu mengembangkan dirinya. Orang tua juga dapat mempersiapkan diri dengan menyediakan bermacam mainan yang tidak terbatas pada jenis kelamin anak, sehingga anak dapat lebih mengeksplorasi. 
Orang tua diharapkan meningkatkan interaksi dan komunikasi dengan anak, sehingga secara tidak langsung akan meningkatkan kemampuan sosial anak. Selain itu, orang tua dihimbau untuk mengurangi penggunaan gadget dan memberikan kegiatan alternatif bagi anak. Orang tua juga dapat mendukung mengembangkan minat dan bakat anak dengan mengikutkan dalam kegiatan yang disukai anak, disamping hanya mengembangkan kemampuan akademis anak.

Sementara itu, beberapa saran praktis yang dapat peneliti berikan kepada guru dan sekolah untuk meningkatkan kemampuan sosial bagi anak dengan autisme adalah dengan menerapkan prinsip DIR Floortime dalam kegiatan belajar mengajar dengan mengikuti preferensi anak agar dapat meningkatkan interaksi dan komunikasi anak. Guru dan sekolah anak dengan autisme juga perlu memberikan tugas yang sesuai dengan kapasitas dan minat anak, dikarenakan anak dengan autisme cenderung kesulitan untuk mengikuti kegiatan terstuktur yang dapat menghambat proses belajar anak. Selain itu, guru dan sekolah juga perlu menyadari bahwa setiap anak degnan ASD pasti memiliki bakat. Maka, pihak sekolah dan guru dapat membantu menemukan bakat tersebut dengan melakukan observasi untuk mengetahui bidang minat dan kelebihan anak, sehingga dapat berfokus untuk mengembangkan bakat anak disamping kemampuan akademis anak.

\section{DAFTAR PUSTAKA}

American Psychiatric Association. (2013). Diagnostic and statistical manual of mental disorders, Fifth edition. Washington, D.C.: American Psychiatric Publishing.

Anderson, K. (2010). Visual support \& beyond. Diunduh dari http://www.visualsupportsandbeyon d.co.uk/how/downloads/Sensory\%2 0Problems\%20Assessment\%20Que stionnaire\%20(2010).pdf

Bellini, S. (2006). Building Social
Relationships: A Systematic Approach to Teaching Social Interactin Skills to Children and Adolescents with Autism Spectrum DIsorders and Other Social Difficulties. Diunduh dari https://www.ocali.org/up_doc/Autis m_Social_Skills_Profile.pdf pada 8 Maret 2018

Bellini, S., \& Hopf, A. (2007). The development of the Autism Social Skills Profile: A preliminary analysis of psychometric properties. Focus on Autism and Other Developmental Disabilities, 22(2), 80-87.

Berk, L. E. (2014). Development through the lifespan, 6th Edition. Boston : Pearson Education.

Blaney, P. H., Krueger, R.F. \& Millon, T. (2015). Oxford textbook of psychopathology. Oxford University Press.

Canadian Paediatric Society. (2017). Screen time and young children: Promoting health and development in digital world. Paediatrics \& Child Health, 2017, 461-468

Charman, T. \& Stone, W. (2006). Social \& communication development in autisme spectrum disorders: Early identification, diagnosis \& intervention. New York: The Guilford Press.

Cohen, S., Fulcher, B. D., Rajaratnam, S. M., Conduit, R., Sullivan, J. P., St Hilaire, M. A., ... \& Braga-Kenyon, P. (2018). Sleep patterns predictive of daytime challenging behavior in individuals with low-functioning autism. Autism Research, 11(2), 391-403.

Cook, C. R., Gresham, L. K., Barreras, R. B., Thornton, S., \& Crews, S. D. (2008). Socials skills training for secondary students with emotional and/or behavioral disorders: A review and analysis of the metaanalytic literature. Journal of Emotional and Behavioral Disorders, 16, 131-144.

Dionne, M., \& Martini, R. (2011). Floor 
time play with a child with autisme: A single-subject study. Canadian Journal of Occupational Therapy, 78(3), 196-203.

Dixon, D. R., Tarbox, J., \& Najdowski, A. (2010). Social skills in autisme spectrum disorders. In Social behavior and skills in children (pp. 117-140). Springer, New York, NY.

Greesspan, S. \& DeGangi, G.A. (2000). Functional Emotional Assessment Scale. Pediatric Disorders of Regulation in Affect and Behavior, pp.341-360

Greenspan, S., \& Wieder, S. (2008). DIR ${ }^{\circledR} /$ Floortime ${ }^{\mathrm{TM}} \quad$ Model. The International Council on Developmental and Learning Disorders.

Greenspan, S. I. (2001). The affect diathesis hypothesis: The role of emotions in the core deficit in autism and in the development of intelligence and social skills. Journal of Developmental and Learning Disorders, 5(1), 1-45.

Hess, E. B. (2013). DIR $® /$ Floortime ${ }^{\mathrm{TM}}$ : Evidence based practice towards the treatment of autisme and sensory processing disorder in children and adolescents. International Journal of Child Health and Human Development, 6(3), 267-274.

Howlin, P. (2000). Autism and intellectual disability: diagnostic and treatment issues. Journal of the Royal Society of Medicine, 93(7), 351-355.

ICDL DMIC. (2005). Diagnostic Manual for Infancy and Early Childhood. Bethesda : Interdisciplinary Council on Developmental and Learning Disorder.

Johns, B. H., Crowley, E. P., \& Guetzloe, E. (2005). The central role of teaching social skills. Focus on Exceptional Children, 37(8).

Lal, R., \&Chhabria, R. (2013). Early intervention of autisme: A case for Floor Time approach. In Recent Advances in Autism Spectrum
Disorders-Volume I. InTech. Lang, R., Hancock, T. B., \& Singh, N. N. (Eds.). (2016). Early Intervention for Young Children with Autism Spectrum Disorder. Springer.

Lang, R., Hancock, T. B., \& Singh, N. N. (Eds.). (2016). Early intervention for young children with autism spectrum disorder. Springer.

Levesque, R. J. (Ed.). (2011). Encyclopedia of adolescence. Springer Science \& Business Media.

Lindgren, S., \& Doobay, A. (2011). Evidence-based interventions for autisme spectrum disorders. The University of Iowa, Iowa.

Little, S. G., Swangler, J., \& Akin-Little, A. (2017). Defining Social Skills. In Handbook of Social Behavior and Skills in Children (pp. 9-17). Springer, Cham.

Lord, C., Cook, E. H., Leventhal, B. L., \& Amaral, D. G. (2000). Autism spectrum disorders. Neuron, 28(2), 355-363.

Mash, E.J., \& Wolfe, D.A. (2013). Abnormal child psychology (5 $5^{\text {th }}$ ed.). Boston, MA: Wadsworth, Cengage Learning.

Matheson, R. C. (2016). DIR Floortime Therapy Rebecca C. Matheson Lynchburg College July 2016.

Mercer, J. (2015). Examining DIR/Floortime ${ }^{\mathrm{TM}}$ as a treatment for children with autisme spectrum disorders: A review of research and theory. Research on Social Work Practice, 27(5), 625-635.

Pangestika, V. (2013). Pengaruh pendekatan floor time terhadap kemampuan berbahasa pada anak autistik. Journal-online.um.ac.id

Pajareya, K., \& Nopmaneejumruslers, K. (2011). A pilot randomized controlled trial of DIR/Floortime ${ }^{\mathrm{TM}}$ parent training intervention for preschool children with autistic spectrum disorders. Autism, 15(5), 563-577.

Pelios, L. V., \& Lund, S. K. (2001). A selective overview of issues on classification, causation, and early 
intensive behavioral intervention for autisme. Behavior Modification, 25(5), 678-697.

Pijar Psikologi. (2017). Apa Kabar anak dengna autisme di Indonesia. Diunduh pada 2 Januari 2018 dari http://pijarpsikologi.org/apa-kabaranak-dengan-autisme-di-indonesia/

Powers, M.D. (2010). Children with autisme: A parent's guide. Bethesda, MD: Woodbine House.

Rao, P. A., Beidel, D. C., \& Murray, M. J. (2008). Social skills interventions for children with Asperger's syndrome or high-functioning autisme: A review and recommendations. Journal of autisme and developmental disorders, 38(2), 353-361.

Robinson, S., Goddard, L., Dritschel, B., Wisley, M, and Howlin, P. (2009). "Executive functions in children with autism spectrum disorders." Brain and cognition 71, no. 3 (2009): 362-368.

Ryan, J. B., Hughes, E. M., Katsiyannis, A., McDaniel, M., \& Sprinkle, C. (2011). based educational practices for students with autism spectrum disorders. Teaching Exceptional Children, 43(3), 56-64.

Sattler, J.M. (2002). Assessment of Children: Behavioral and Clinical Applications. San Diego: Jerome M. Sattler, Publisher, Inc.
Sharpe, D. L., \& Baker, D. L. (2007). Financial issues associated with having a child with autisme. Journal of Family and Economic Issues, 28(2), 247-264.

Shores, R., \& Jack, S. (1996). Special issue on research needs and issues in education for students with emotional and behavioral disorders. Behavioral Disorders, 22(1), 5-7.

Suryana, A. (2004). Terapi autisme, anak berbakat dan anak hiperaktif. Jakarta: Progres Jakarta.

Tse, J., Strulovitch, J., Tagalakis, V., Meng, L., \& Fombonne, E. (2007). Social skills training for adolescents with Asperger syndrome and highfunctioning autisme. Journal of autisme and developmental disorders, 37(10), 1960-1968.

Wall, K. (2004). Autism and early practice: A guide for early years professional, teachers and parents. London: Paul Chapman Publishing.

White, S. W., Keonig, K., \& Scahill, L. (2007). Social skills development in children with autisme spectrum disorders: A review of the intervention research. Journal of autisme and developmental disorders, 37(10), 1858-1868.

Yayasan Ayo Main. (2009). Komunitas DIR/Floortime Indonesia. Diunduh pada 2 Januari 2018 dari http://www.ayomain.org/ 